\title{
From digital activism to algorithmic resistance
}

Emiliano Treré, Cardiff University, TrereE@cardiff.ac.uk

\section{Introduction and outline}

Discourses on algorithms are increasingly populating the media and pervading public conversations. Newspapers are filled with stories on how algorithmic power is impacting our choices in the realms of politics, journalism, music, sport, research, and healthcare. The recent inclusion of the term in the influential "Digital Keywords" volume (Peters 2016) also signals a growing interest in the concept and its consequences within various fields and strands of research in the academia, and especially within media studies. As Gillespie (2016) has pointed out, the term appears in recent scholarship not only as a noun but also increasingly as an adjective, in relation to issues of identity, culture, ideology, accountability, governance, imaginary and regulation. In this chapter, I focus on the changes that algorithmic power is bringing to the realm of politics and the transformations of digital activism. The chapter begins with a brief outline of the significance of algorithms in digital politics. Then, it focuses on two diverse conceptions and manifestations of algorithmic power in politics (algorithm as propaganda/repression and algorithm as appropriation/ resistance) that emerge from the explorations of two case studies.

The first case study is an examination of the contemporary Mexican scenario where institutions and parties have massively deployed algorithmic strategies for propagandistic and repressive purposes. The second case is an investigation of the digital media practices of the Indignados that reveals how Spanish activists used their knowledge of the Twitter algorithm to maximize their visibility, drive the protest narratives, and infiltrate the mainstream media agenda. Lessons on the achievements and challenges of algorithmic power in digital politics are outlined in the conclusions, along with suggestions for future lines of research.

The reflections on the practices of algorithmic resistance and appropriation of the Spanish Indignados are based on twenty semi-structured interviews carried out with a range of social movement organizations: from well-established radical activist groups to informal groups of newly politicized individuals; from traditional hierarchical social movement organizations to horizontal, social movement groups such as anarchist, free culture, or hacker collectives; from non-activist social media users to very experienced tech activists; and from inexperienced citizen journalists to unemployed professional journalists contributing to alternative media. This research was supported by an Insight Development 
Grant from the Social Sciences and Humanities Research Council of Canada [file number 430-2014-00181] held by Dr. Sandra Jeppesen at Lakehead University Orillia, Canada.

\section{Algorithms as ecologies}

Before addressing the role of algorithms in political practice, an assessment of what constitute an algorithm is needed. As Gillespie notes, algorithms "are encoded procedures for transforming input data into a desired output, based on specified calculations” (2014: 167). According to Willson, "algorithms make things happen - they are designed to be executed and to bring about particular outcomes according to certain desires, needs and possibilities" (2016: 4). The metaphor of the recipe is often evoked to define them, since it identifies an endpoint (a meal), provides a list of ingredients, and includes a step-by-step description of a process that describes in a detailed order what needs to be done and at which exact point in time.

If we are to understand the social and political implications of algorithms, we have to take into account that they do not exist in isolation, as separate technical entities, but are instead embedded in multifaceted ecologies of social, cultural and political interactions, and therefore reflect particular ways of conceiving the world (Postigo 2014). Ignoring this “complex assemblage of people, machines and procedures” (Gillespie 2016: 26) may also result in the obscuration of the agency of the people behind algorithms. It may also conceal the fact that we need to look at algorithms in connection to broader global socio-technical shifts such as the process of datafication, i.e. the transformation of social action into online quantified data.

This process, along with the possibilities provided by big data, initially eulogized for its ground-breaking possibilities, has now entered a critical phase with scholars pointing out that the process of datafication and the big data phenomenon are controversial mythologies that have to be critically engaged with (boyd \& Crawford, 2002; Mosco 2014), since they bring with them new regimes of control and discrimination, and generate issues in relation to privacy, surveillance, and inequality (van Dijck 2014, Lyon 2014). Furthermore, algorithms' role should be appraised within the increasingly complex junctions among the process of automation, and the upward diffusion of the Internet of things (Howard 2015).

\section{Algorithms and politics}


Algorithms are deeply affecting the realm of the political. The rapid diffusion of networked devices, paired with the increasing generation of data over multiple platforms, coupled with the massive adoption of social media as tools for political engagement constitute a landscape within which new algorithmic agents proliferate. Most of the studies on algorithms in politics have highlighted the negative consequences of new forms of computational propaganda in relation to political bots (Woolley \& Howard 2016; Woolley 2016; Shorey \& Howard 2016).

Political bots are defined as "the algorithms that operate over social media, written to learn from and mimic real people so as to manipulate public opinion across a diverse range of social media and device networks” (Woolley \& Howard 2016: 4885). Over the last years, political bots have been deployed in numerous countries, from Europe to Latin America, from the US to North Africa and Asia (for a comprehensive charting of the phenomenon, see Woolley 2016) to manipulate public opinion, spread propaganda, create an illusion of popularity, and undermine digital dissent (Treré 2016). As Woolley and Howard (2016: 4886) put it: “computational propaganda is among the latest, and most ubiquitous, technical strategies to be deployed by those who wish to use information technology for social control”.

Mostly scholars appear to be concerned in showing how automated technologies as Twitter trolls and political bots, part of a new kind of robopolitics (Tambini 2016), are hurting democracy by discouraging social media's democratic potential and forcing politicians to limit their digital presence, or abandon online environments altogether (Theocaris at el. 2016). The last electoral campaign in the US has provided a clear example of the deployment of this kind of techniques, with political bots massively spreading erroneous information and fake news to potential voters, often to the benefit of Donald Trump (Resnick 2016). Indeed, these studies are able to account for the new ramifications of the dark side of digital politics, but there is often a sense of hopelessness within this strand of research, as if social actors were completely deprived of their agency in front of these new forms of algorithmic manipulation.

While it is key to examine the depths of the dark side of the algorithm, it is also pivotal to explore the ways through which, in specific socio-political contexts, algorithmic power redefines activists' practices, and to investigate the conditions under which social movement actors are able to repurpose the power of big data to pursue social justice (Dencik et al. 2016; Milan 2015). Indeed, in the current scenario we are also experiencing unpredicted forms of algorithmic resistance that acquire a variety of shapes: activists, civil 
society organizations and radical tech groups are proving to be increasingly more skillful in unmasking algorithmic propaganda on social media, showing through data visualizations how governments use bots to undermine dissent, and exploiting the power of the Twitter algorithm to boost a protest movement's popularity. In the following sections, we will then look at both side of algorithmic political power. Drawing on the case of contemporary Mexico, we will shed light on algorithms used as propaganda and repression; then, based on the experience of the Indignados in Spain, we will instead look at manifestations of algorithms as appropriation and resistance.

\section{Algorithm as propaganda}

Before the 2012 general elections, Mexican politicians had never considered politics through digital platforms a priority, relying instead on the powerful media propaganda system provided by television as their main channel for campaigning. This is not to say that during the 2012 elections the mainstream media were not important: the role of the socalled Mexican telecracy - the media television duopoly Televisa-TvAzteca, which controls 99\% of the market (Huerta-Wong and Gómez 2013) was indeed pivotal, since - as documented by numerous investigative journalists (Tuckman 2012; Villamil 2010) - for six years the Mexican media titan Televisa shaped the candidacy of Enrique Peña Nieto (EPN) of the PRI party (the current Mexican president), while simultaneously delegitimising his left-wing opponent Manuel López Obrador. But the 2012 elections also witnessed what some saw as an explosion of digital politics, with politicians conquering social media to engage in dialogue with citizens.

However, what was perceived by a superficial look as an embrace of the digital sphere for fostering citizen engagement, revealed to more analytical eyes that these politicians mostly considered online spaces as sites for both the premeditated construction of consensus and the algorithmic construction of consent, rather than environments for reinforcing democracy through genuine dialogue and participation. Mexican scholar Octavio Islas has framed this behaviour as “authoritarian engineering” (Islas 2015:1), a concept similar to "computational propaganda" that indicates the adoption by Mexican politicians of opaque online strategies to boost popularity and undermine oppositional voices.

Studies of the social media strategies of Mexican politicians during the 2012 campaign underline that an intensified use of digital technologies did not correspond to an increase in democratic participation between candidates and voters, but was instead 
constituted by a massive deployment of strategies including: the creation of false universes of followers; the use of political bots to automatically generate tweets; and the hiring of trolls (people who tweet in favour of a candidate, and against their opponent); and ghost followers (empty accounts aimed at boosting a candidate's followers). By employing these strategies, Mexican politicians discarded the possibility of using digital platforms to include voters' feedback into their decisions and incorporate democratic visions into their ways of doing politics (Ricaurte Quijano 2013).

These algorithmic strategies were paired by the activities of an army of so-called PRI ectivistas ('ectivists'), dedicated to tweeting according to the instructions of EPN's campaign leaders, and trying to counteract, isolate or sabotage criticisms of PRI from civil society actors. The ectivist network was formed in December 2009, and ectivist leaders have always claimed to be nothing more than a network of independent young volunteers and PRI supporters. But, as other researchers have recognized (Figueiras 2012), the organisation of an estimated 100,000 ectivists (Islas 2015) was used systematically during the PRI campaign to successfully spread and situate Peña Nieto's image on digital media. In particular, this network was 'activated' when Peña Nieto’s public image suffered: for instance, after his speech at the Guadalajara International Book Fair, when he was unable to accurately name three books that had influenced his life, and when the student movement \#YoSoy132 emerged in May 2012, condemning the dangerous interconnections between media and politics that the PRI candidate impersonated.

Although one of Peña Nieto’s campaign managers (who later became Secretary of Education) acknowledged in May 2012 that 20,000 ectivists were tweeting without receiving any monetary compensation, the issue is controversial, with other sources showing that thousands of ectivists were actually hired to perform their activities. The Mexican case study clearly shows the possibilities for impacting, distorting and manufacturing public opinion within digital environments that institutional parties with immense financial resources like the PRI have at their disposal.

\section{Algorithm as repression}

In the Mexican scenario, the use of algorithms for propaganda goes together with its use for repressive purposes. Since 2012, political activists and civil society organisations have denounced the dangers algorithmic attacks on social media, arguing that they criminalise protest and segregate dissident voices, and underlining the need to act immediately to prevent their intensification. Political strategies that rely on digital technologies to 
undermine dissent through the use of political bots have been enhanced in the years since the 2012 election, up to the point where they have become an essential component of the government's modus operandi, used repeatedly during 2013.

For instance, EPN critics mobilising for the \#MarchaAntiEPN (March against Peña Nieto) on Twitter were systematically attacked and blocked online, and dissident voices were 'drowned' on various occasions by orchestrated bot attacks (Verkamp and Gupta 2013). A study, commissioned by the news programme of a liberal Mexican journalist and carried out by the data-mining agency Mesura, exposed the massive use of bots to build an illusion of online support for a controversial energy reform (Aristegui Noticias 2015). Mesura documented the systematic deployment of bots to tweet and re-tweet in support of the reform, discovering that the time gap between the sending of a supportive original message and its re-tweeting was too short to be accomplished by a human being. The report's pessimistic conclusions warned about the risks to which citizens are exposed in an era when the importance of digital politics is growing day by day, and when those in power have no ethical problems with manipulating public perception, creating new forms of authoritarianism enabled by digital technology (Soto 2013).

On 26 September 2014, a group of students departed the Ayotzinapa Rural Teachers' College for a protest in the city of Iguala (about $130 \mathrm{~km}$ away) but they never arrived. At least three students were killed and another 43 remain missing. The Mexican government's official version is that the students were killed after being handed over to the Guerreros Unidos cartel on the orders of the mayor of Iguala, but investigations conducted by various media outlets, such as the Mexican critical magazine Proceso and the US publication The Intercept portrayed a darker picture of government complacency. After the event, several activists started to protest on social media, and the Twitter hashtag \#YaMeCanse (I am tired) - which expressed the feeling of not being able to tolerate any more violence in the country - soon became the core for mobilising and spreading information.

Journalist Erin Gallagher, who covers political mobilizations for the online magazine Revolution News, soon noticed something atypical in the search results for the \#YaMeCanse hashtags: that they were flooded with tweets including the hashtag but no other content apart from random punctuation marks. The accounts tweeting this kind of empty content were in fact bots that lacked followers, and were tweeting automatically. The noise they created made it difficult for citizens to share information using \#YaMeCanse, and thus the hashtag dropped out of Twitter's trending topics. 
Mexican blogger and data-mining analyst Alberto Escorcia has discovered a reliable way of detecting bot accounts by examining the number of connections a Twitter account has with other users, and has been documenting the use of bots in Mexico to sabotage protests by preventing information from spreading, and to send death threats to specific activists in a wide array of political campaigns in the last years. For instance, since February 2015, professor, activist and blogger Rossana Reguillo has received regular death threats on various social media platforms (Saucedo Añez 2015). Particularly harsh attacks via Twitter lasted more than two months, and data-mining analysis of the Twitter campaign revealed that bots and trolls were responsible for most of the attacks. As these cases show, algorithmic propaganda and repression are particularly virulent in the Mexican scenario, where the propagandistic modus operandi of mainstream media have infiltrated the digital sphere. But the scenario is not entirely dark, as the previous examples attest, various bloggers, journalists and tech activists are developing diverse tactics of algorithmic resistance through which they are able to expose and sometimes counteract the dirty digital strategies of institutions and parties.

\section{Algorithm as appropriation and resistance}

The 15M or Indignados movement that emerged in 2011 in Spain developed extremely sophisticated forms of digital political action (Candón Mena 2011; Gerbaudo 2012) and it is thus considered a powerful laboratory for experimentation and innovation in practices of political communication that is contributing to the reconfiguration of democracy (Feenstra et al. 2016). This movement refined and perfected the repertoires of contention and communication of previous Spanish mobilizations (such as the 13M demonstration in 2004 and the Movement for the Right to Housing that emerged in 2006), leading to the development of sophisticated practices of hybrid synchronization between online and offline activism, and to the appropriation of multiple digital media platforms to create and spread content, organize, mobilize, and document protest.

The digital activism of the Indignados has been described by both scholars and activists themselves as technopolitics, a multifaceted form of communicative action that is a complex blend of technological knowledge and digital expertise used for radical political purposes with the technology itself envisaged as a site of struggle (Alcazan et al. 2012; Monterde 2015; Toret et al. 2015; Treré et al. 2017). The origins of technopolitics are deeply rooted in the non-hierarchical, collaborative and open spirit of the Free Culture Movement (Fuster Morell 2012; Postill 2016), and in the principles of positive meritocracy 
and the remix ethos of hacker ethics (Himannen 2001). Open Source culture has shaped the agenda of the movement in relation to information and knowledge policies and practices, and has situated the digital commons as a pivotal topic and a crucial site of contention for the Indignados (Fuster Morell \& Subirats 2012). Moreover, it has molded the movement's organizational logic through horizontal, decentralized coordination that massively relied on digital media.

The technopolitical practices of the Indignados covered a wide and diverse ecology of platforms used for collective action. On one side, activists produced their own radical media, such as the N-1 alternative social media platform, the ¡Democracia Real YA! Website, and various media projects such as Sol TV, Ágora Sol Radio, Toma La Tele and the printed newspaper Madrid15M. Furthermore, they also heavily relied on free and opensource software, advocating for technological infrastructure sovereignty and selfdetermination where viable.

But what has been a fundamental character of technopolitics is the tactical and massive appropriation (that Spanish media activists qualified as "hacking social media") of corporate social platforms as Twitter and Facebook in order "to transform them in real weapons of massive information diffusion” (SuNotissima et al. 2012: 18). Through the strategic appropriation of social media, the Indignados were capable not only of launching calls for action and organizing mobilizations, but also of influencing journalistic coverage and situate their claims in the media agenda. Through social media appropriation, Spanish activists were able to achieve that their 15 May call for action was mentioned 37 times by printed press (Candón Mena 2013), and in many other occasions they obtained international press coverage on newspapers as The Washington Post and The New York Times, making it impossible for Spanish media outlets to ignore their claims (Toret et al. 2015).

One of the most effective strategies adopted by $15 \mathrm{M}$ activists consisted in the systematic creation of trending topics on Twitter, which was carefully planned using a combination of internal communication technologies, and social media platforms. Internal communication tools as pads (digital notepads for collective writing such as Titanpad) were used to collectively select possibly successful hashtags and build the narrative of the protest, while external social media platforms as Twitter were deployed to massively spread the information and obtain the desired outcome. Inside the pads, activists first brainstormed diverse possible hashtags in order to reach an agreement over the most effective one for the specific political campaign that was tackled. Once a hashtag was chosen, an array of potential tweets was created accordingly and sent to other activist collectives through other 
internal communication tools such as direct messaging services (WhatsApp and Telegram) and mailing lists.

This type of sophisticated digital action is based on the collective synchronization of thousands of accounts that tweet at the same time selecting among the already provided tweets. To reach this aim, it is fundamental to rely on an already established network of activists' profiles that can be activated at any time. This kind of technopolitical practice represents a clear form of resistance and appropriation of the Twitter algorithm. Interviewees themselves admitted that this tactic originates precisely from trying to understand how the Twitter algorithm worked and how it could be exploited for boosting the movement popularity and influence the mainstream media agenda. Through daily practices of self-reflexivity on the potential of social media, activists saw that general trending topics had a short cycle of 24 hours maximum, and that in order to create them all the accounts had to tweet with the same hashtag simultaneously, and that the hashtag had to be a previously unused one. The Indignados' capacity to create trending topics and master this new kind of viral politics is unmatched within contemporary movements. It is based on the fundamental role that hackers and techies played within the movement, acting as a techvanguard that applied their tech expertise not only for the creation of radical alternative media, but above all for the appropriation and cyber-material detournement (Galis \& Neumayer 2016) of corporate social media.

This tech expertise manifests itself also as "radical media education" (Coslado 2015), since basically every political action and campaign of the last seven years in the Spanish scenario has been accompanied by a flow of online tutorials, manuals and skillshare workshops about how to increase the effectiveness of social media campaigns by exploiting corporate social media’s algorithms (Feenstra et al 2016).

This new forms of algorithmic resistance are dissimilar from the spontaneous 'smart mobs' that had characterized the Spanish scenario ten years before the Indignados (Sampedro et al. 2005). They signal a new level of technological awareness and finesse in the realm of digital activism, and also sharply contrast enthusiastic claims about the complete spontaneousness of digital protests, because they constitute carefully envisioned and planned political actions.

\section{Conclusions: Contextualizing algorithmic power}

Throughout this chapter, we have begun to appraise the relevance of algorithmic power within contemporary politics and digital activism. The two case studies I have examined 
display the ambivalences inherent in this kind of power. While the in the Mexican scenario conventional politics and institutions have used algorithmic power for propagandistic and repressive purposes, in Spain social movements have been able to repurpose this power in order to pursue social change. What are the main lessons we can learn from this brief journey into algorithmic power? First of all, the importance of looking at the agency involved in this kind of power. If we conceive of algorithms as ecologies of humans, machines and procedures, in order to evaluate their role we have to learn how to disentangle, and make sense of their complex interrelations. This means also contextualizing algorithmic power in order to assess which actors are using these mechanisms, for which purposes and with which level of expertise. The Mexican case illustrates that civil society have been slower than institutional politics in 'catching up' with the power of the algorithm in politics, while the Spanish case shows exactly the contrary. These two contextual analyses demonstrate that understanding contemporary digital politics increasingly means understanding how algorithmic power works.

This power is reorienting the new practices of digital activism within movements and civil society organizations. In this evolving scenario, digital media literacy is increasingly relevant, as social actors have to learn not only how to unmask and denounce new authoritarian digital strategies carried out by governments and parties, but also, at the same time, they need to develop sophisticated techniques and tactics to 'bend the algorithm' according to their socio-political needs, in order to pursue social justice and political change.

\section{References}

Alcazan, A. et al. (2012) Tecnopolítica Internet y R-evoluciones. Sobre la centralidad de las redes digitales en el \#15M. Barcelona: Icaria.

Aristegui Noticias (2012) 'La Cargada de Funcionarios en Twitter a Favor de \#reformaenergética', http://aristeguinoticias.com/2609/mexico/la-cargada-de-funcionarios-entwitter-a-favor-de-reformaenergetica/, accessed 25 January 2017.

Coslado, Á. B. (2015) 'Comunicación educativa y cultura política en el Movimiento 15-M. Aproximación teórica y reflexiones preliminares en torno a un estudio etnográfico’, kultur, 2(4), pp. 179-192.

Boyd, D. and Crawford, K. (2012) 'Critical Questions for Big D ata: Provocations for a Cultural, Technological, and Scholarly Phenomenon', Information, Communication and Society 15.5, pp. 662-79

Candón Mena, José (2013) Toma la calle, toma las redes: El movimiento 15M en Internet. Sevilla: Atrapasueños. 
Dencik, L., Hintz, A., \& Cable, J. (2016) 'Towards data justice? The ambiguity of anti-surveillance resistance in political activism’, Big Data \& Society, 3(2).

Feenstra, R., Tormey, S., Casero-Ripollés, A. y Keane, J. (2016) La reconfiguración de la democracia: el laboratorio político español. Granada: Comares.

Figueiras, L. (2012) 'El Movimiento Estudiantil en el Proceso Electoral 2012', in L. Figueiras (ed.), Del 131 al \#YoSoy132. Elección 2012, México: Comunicación y Política Editores.

Fuster Morell, M. (2012) The free culture and 15M movements in Spain: Composition, social networks and synergies. Social Movement Studies: Journal of Social, Cultural and Political Protest 11 (3-4), pp. 386-392.

Galis, V., \& Neumayer, C. (2016) Laying claim to social media by activists: a cyber-material détournement. Social media+ society, 2(3).

Gerbaudo, P. (2012) Tweets and the streets. Social media and contemporary activism. London: Pluto.

Gillespie, T. (2014) 'The relevance of algorithms' in T. Gillespie, P. J. Boczkowski, \& K. Foot (eds.) Media technologies: Essays on communication, materiality, and society. Cambridge: MIT Press, pp. 167-194.

Himanen, P. (2001) The hacker ethic and the spirit of the information age. New York: Random House.

Huerta, W.E. and Gómez, R. (2013) 'Concentración y diversidad de los medios de comunicacion y las telecomunicaciones en México’, Comunicación y Sociedad, no. 19, pp. 113-152.

Islas, O. (2015) 'Los Neoectivistas: El Recurso contra la Participación Ciudadana', www.etcetera.com.mx/articulo/los neoectivistas el recurso contra la participacion ciudadana./35375/, accessed 22 January 2017.

Lyon, D. (2014) Surveillance, Snowden, and Big Data: Capacities, consequences, critique. Big Data \& Society, 1(2).

Milan, S. (2015) 'When Algorithms Shape Collective Action: Social Media and the Dynamics of Cloud Protesting', Social Media and Society 18.8, pp. 887-900.

Monterde, A. (2015) Emergencia, evolución y efectos del movimiento-red 15M (2011-2015). Una aproximación tecnopolítica. Barcelona: UOC-IN3.

Mosco, V. (2014) To the Cloud: Big Data in a Turbulent World, New York NY: Paradigm

Peters, B. (Ed.).(2016) Digital keywords: a vocabulary of information society and culture. Princeton: Princeton University Press.

Postigo, H. (2014, April) 'Capture, fixation and conversation: How the matrix has you and will sell you, part 3/3’, Culture Digitally, http://culturedigitally.org/2014/04/capture-fixation-andconversation-how-the-matrix-has-you-and-will-sell-you-part33/\#sthash.6sGBTcmy.mXWelSyy.dpuf, accessed 8 January 2017. 
Postill, J. (2016) 'Freedom technologists and the future of global justice', https://www.tni.org/en/publication/freedom-technologists-and-the-future-of-global-justice, accessed 19 January 2017.

Resnick, G. (2016) 'How Pro-Trump Twitter Bots Spread Fake News', The Daily Beast, 17 November, http://www.thedailybeast.com/articles/2016/11/17/how-pro-trump-twitter-botsspread-fake-news.html, accessed 18 January 2017.

Ricaurte Quijano, P. (2013) 'Tan Cerca de Twitter y tan Lejos de Los Votantes: Las Estrategias de los Candidatos Presidenciales Mexicanos durante la Campaña Electoral de 2012', Versión 31: pp. 118-32

Sampedro, V.F. (Ed.) (2005) 13-M: Multitudes on line. Madrid: Catarata.

Saucedo Añez, P.C. (2015) 'Amenazas de muerte en la red contra investigadora y activista mexicana Rossana Reguillo’, GlobalVoices, https://es.globalvoices.org/2015/03/04/amenazasde-muerte-en-la-red-contra-investigadora-y-activista-mexicana-rossana-reguillo/, accessed 3 February 2017.

Shorey, S., \& Howard, P. N. (2016) 'Automation, Algorithms, and Politics| Automation, Big Data and Politics: A Research Review’, International Journal of Communication, 10, 24.

Soto, J.C. (2013) ‘Tecnoautoritarismo’, http://desmesura.org/firmas/tecno-autoritarismo, accessed 4 January 2017.

Tambini, D. (2016) 'In the new robopolitics, social media has left newspapers for dead', The Guardian, 18 November, https://www.theguardian.com/commentisfree/2016/nov/18/robopolitics-social-mediatraditional-media-dead-brexit-trump, accessed 15 January 2017

Theocaris, Y. et al. (2016) 'Twitter Trolls are actually hurting democracy'. The Washington Post, 4 November, https://www.washingtonpost.com/news/monkey-cage/wp/2016/11/04/twitter-trollshurt-democracy-more-than-you-realize-heres-how/, accessed 12 January 2017

Toret, J. (Ed.) (2015) Tecnopolítica y 15M: La potencia de las multitudes conectadas. Barcelona: UOC.

Treré, E. (2016) 'The Dark Side of Digital Politics: Understanding the Algorithmic Manufacturing of Consent and the Hindering of Online Dissidence', IDS Bulletin, 47(1).

Treré, E., Jeppesen, S. \& Mattoni, A. (forthcoming 2017) Comparing Digital Protest Media Imaginaries: Anti-austerity Movements in Spain, Italy \& Greece, TripleC.

Tuckman, J. (2012) 'Mexican Media Scandal: Secretive Televisa Unit Promoted PRI Candidate', The Guardian, 26 June, www.theguardian.com/world/2012/jun/26/mexican-media- scandaltelevisa-pri-nieto

van Dijck, J. (2014) Datafication, dataism and dataveillance: Big data between scientific paradigm and ideology. Surveillance and Society, 12(3), 197-208.

Verkamp, J-P. and Gupta, M. (2013) 'Five Incidents, One Theme: Twitter Spam as a Weapon to Drown Voices of Protest', unpublished presentation from 3rd USENIX Workshop on Free and Open Communications on the Internet, Berkeley, California

Villamil, J. (2010) El Sexenio de Televisa: Conjuras del Poder Medi tico, México DF: Grijalbo 
Willson, M. (2017) Algorithms (and the) everyday. Information, Communication \& Society, 20(1), 137-150.

Woolley, S. C., \& Howard, P. N. (2016) Automation, Algorithms, and Politics| Political Communication, Computational Propaganda, and Autonomous AgentsIntroduction. International Journal of Communication, 10, 9.

Woolley, S. (2016) Automating power: Social bot interference in global politics. First Monday, 21(4). Retrieved from http://firstmonday.org/ojs/index.php/fm/article/view/6161/5300 